\title{
STRATEGI KREATIF KAMPANYE SOSIAL ORGANISASI BERBASIS KOMUNITAS “RUMAH CEMARA” BANDUNGMELALUI MEDIA SOSIAL
}

\author{
R.A. Dita Saraswati \\ (Email: radita.saraswati@gmail.com) \\ Program Studi Desain Komunikasi Visual \\ Fakultas Seni Rupa dan Desain \\ Universitas Kristen Maranatha \\ JI. Prof. Drg. Surya Sumantri No.65, Bandung, Indonesia
}

\begin{abstract}
ABSTRAK
Pada tahun 2014 kampanye sosial dan penyuluhan HIV/AIDS telah dijalankan oleh pemerintah atau Kementerian Kesehatan Republik Indonesia, yang bertujuan agar setidaknya kaum muda dapat mengenal bagaimana pencegahan serta informasi lainnya terkait mitos dan fakta tentang HIV dan AIDS. Berbeda dengan kampanye pemerintah yang bersifat preventif, sebuah organisasi yang dinamakan Rumah Cemara di Kota Bandung lebih berfokus pada orang yang sudah terinfeksi HIV/AIDS, terutama golongan anak muda dengan latar belakang mantan pecandu narkoba.Rumah Cemara adalah organisasi berbasis komunitas yang bertujuan meningkatkan kualitas hidup orang dengan HIV/AIDS dan pecandu NAPZA di Indonesia melalui pendekatan dukungan sebaya.Rumah Cemara merupakan jejaring orang dengan HIV/AIDS dan pecandu NAPZA terbesar di Jawa Barat, Indonesia.Dengan teknik wawancara, dokumentasi serta studi literatur mengenai kampanye dan media sosial, penulis bermaksud untuk menganalisis peran media sosial dan strategi kreatif kampanye yang dijalankan organisasi ini dalam kurun waktu 3 tahun, dari 2013 hingga 2015. Dalam strategi kampanye tersebut, Rumah Cemara berhasil mengundang perhatian bukan saja para pengidap dan pecandu narkoba, tetapi masyarakat umum Kota Bandung mengenai problematika diskriminasi terhadap para pengidap HIV/AIDS. Penelitian ini bertujuan untuk memaparkan strategi kreatif dalam media sosial yang semakin ramai digunakan oleh masyarakat indonesia. Penelitian ini juga bermanfaat sebagai tinjauan atau referensi bagi kampanye sosial bagi organisasi/ komunitas lainnya di indonesia.
\end{abstract}

Kata Kunci: HIV/AIDS; komunitas; mediasosial; strategikreatif.

\begin{abstract}
In 2014 social campaign and counseling for HIV and AIDS has been run by government or Health Ministry of the Republic of Indonesia, which aimed to make young people know how to prevent HIV/AIDS withother information related to myths and facts. Different with the government preventive campaign, an organization called Rumah Cemara in Bandung focusing to people that already infected by HIV/AIDS, especially teenager with former drug addicts background. Rumah Cemara is a community-based organization which aims to improve the quality of people living with HIV and Napza addict in Indonesia through peer approach support. Rumah Cemara is the largest network of people with HIV and Napza in West Java Province in Indonesia. With interview technique, documentation as well as literature studies of campaign and social media, the writer intend to analyze the role of social media and creative strategy campaign this organization runs for over 3 years, from 2013 to 2015. In their campaign strategy, they succesfully gain attention not only from the people living with HIV/drug addicts, but also the major society of Bandung about the discrimination problems towards the people living with HIV/AIDS. This research aims to describe the creative strategy in socialmedia which popularly used by indonesian. This research also beneficial as a reference and reviews for social campaign for organization / other communities in Indonesia.
\end{abstract}

Keywords: community; creative strategy; HIV/AIDS; social media. 


\section{PENDAHULUAN}

Kampanye HIV/AIDS pertama kali yang pernah diangkat oleh pemerintah dan lembaga sosial masyarakat bermula pada tahun 1989 yang bermula fokus pada penyakitnya, kemudian berfokus pada diskriminasi terhadap orang yang hidup dengan HIV/AIDS.Hal ini menandakan adanya perubahan fokus masalah bahwa masyarakat Indonesia yang hidup dengan HIV/AIDS termasuk salah satu lapisan dalam masyarakat yang mengalami diskriminasi yang cukup signifikan. Menurut AIDS Watch Indonesia (www.aidsindonesia.com) dan situs resmi Rumah Cemara (www.rumahcemara.org), estimasi orang dengan HIV dan AIDS di Indonesia tahun 2012 adalah sebanyak 591.823 sedangkan saat ini ODHA (orang yang hidup dengan HIV dan AIDS) yang sudah kita ketahui baru berjumlah 150.296. Hal ini berarti baru sekitar 30\% ODHA yang telah terdeteksi.Jawa Barat termasuk dalam urutan ke-4 dengan jumlah 13.507 jiwa.

Pada tahun 2014 kampanye sosial dan penyuluhan telah dijalankan oleh pemerintah atau Kementerian Kesehatan Republik Indonesia adalah Kampanye Aku Bangga Aku Tahu (ABAT), yang bertujuan agar setidaknya kaum muda dapat mengenal bagaimana mencegah HIV dan AIDS serta informasi lainnya terkait mitos dan fakta tentang HIV dan AIDS. Kampanye ini mengangkat slogan Jiwa yang tegar NO Narkoba, Hati yang murni NO Seks Bebas. Sampai dengan tahun 2014, 33 Provinsi sudah melakukan orientasi fasilitator Kampanye ABAT di 210 kabupaten/kota.Berbeda dengan kampanye pemerintah yang bersifat preventif, sebuah organisasi yang dinamakan Rumah Cemara lebih mengacu dan berfokus kepada orang yang sudah terinfeksi HIV/AIDS, terutama golongan anak muda dengan latar belakang mantan pecandu narkoba. Rumah Cemara adalah organisasi berbasis komunitas yang bertujuan meningkatkan kualitas hidup orang dengan HIV/AIDS dan pecandu NAPZA (kepanjangan dari Narkotika, Alkohol, Psikotropika dan Zat adiktif lain) di Indonesia melalui pendekatan dukungan usiasebaya.

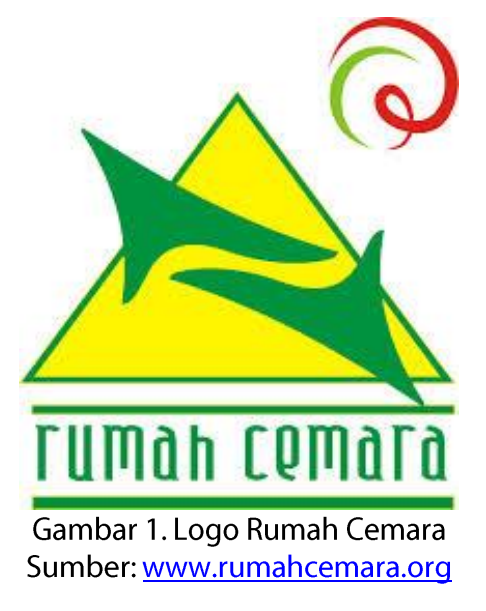


Rumah Cemara didirikan pada tahun 2003 oleh lima orang mantan pecandu, Rumah Cemara merupakan jejaring orang dengan HIV/AIDS dan pecandu NAPZA terbesar di Jawa Barat, Indonesia. Rumah Cemara memiliki 45 staf, 70\% pria dan 30\% wanita, dengan rentang umur 20-35 tahun. Hampir seluruh staf adalah mantan pecandu dan 85\% adalah HIV positif. Terhitung pada tahun 2009, organisasi ini telah merehabilitasi 200 pecandu narkoba dan memiliki anggota sebanyak 4.317 orang dengan HIV/AIDS, serta 1.276 orang yang tersebar di tigakota di Jawa Barat.Pada mulanya kegiatan sosial pada masyarakat yang dijalankan oleh Rumah Cemara adalah melalui penyuluhan langsung dengan pendekatan sebaya pada golongan remaja.

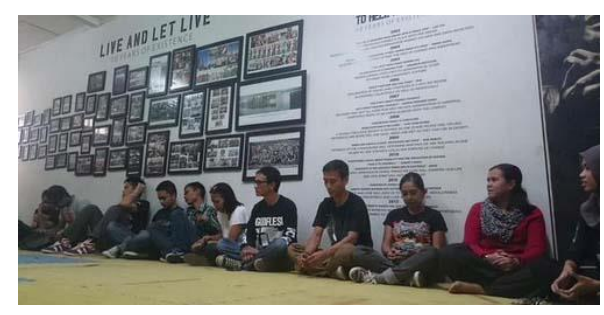

Gambar 2. Kegiatan di Rumah Cemara Sumber: www.rumahcemara.org

Menurut informasi yang dituliskan pada media sosial Facebook, dengan tingginya stigma dan diskriminasi sosial yang dialami oleh ODHA (orang yang hidup dengan HIV dan AIDS) dan pengguna NAPZA, Rumah Cemara sebagai organisasi komunitas HIV dan narkoba memberikan kesempatan bagi mereka yang telah sering mengalami pengucilan sosial dan tersingkirkan untuk mengubah hidupnya melalui bidang olahraga sepakbola. Rumah Cemara memulai program ini sejak 2006 dan pada tahun 2011 meraih prestasi di ajang sepakbola bertaraf internasional (Homeless World Cup). Tujuan utama Rumah Cemara mengirimkan Tim Nasional ke ajang Homeless World Cup bukan semata untuk prestasi, namun juga menginginkan terjadinya perubahan sosial kepada setiap pemain yang dikirim setelah mengikuti kompetisi tersebut melalui sepakbola.

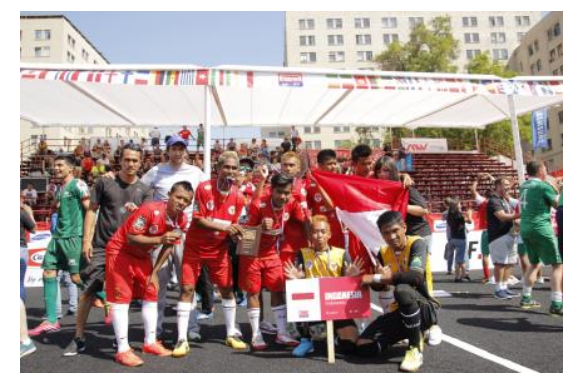

Gambar 3. Foto Tim Rumah Cemara untuk Homeless World Cup Sumber: www.rumahcemara.org

Pada dokumen yang ditautkan di media sosial Facebook juga menyebutkan selain program 
Sepakbola, Rumah Cemara juga memiliki program Tinju sebagai bagian dari program Sports For Development.Pada tahun 2012, Rumah Cemara juga mendirikan sasana Rumah Cemara Boxing Camp (RCBC) dengan Soleh Sundava sebagai Pelatih Kepala dan sudah terdaftar di Pertina (Persatuan Tinju Amatir) Kota Bandung sejak 2013. Melalui program "Sport For Development" ini, secara keseluruhan program ini telah memberikan dampak kepada lebih dari 3.000 penerima manfaat.

Kaitannya dengan persoalan media kampanye yang digunakan oleh organisasi Rumah Cemara yaitu dilatarbelakangi oleh media elektronik (internet) yang menjadi populer di indonesia sebagai sarana komunikasi informasi yang cepat dan efektif yang tumbuh menjadi sumber informasi yang tidak dapat diabaikan.

Sejalan dengan perkembangan teknologi jejaring sosial internetini, berkembang pula teknologi mobile yang dapat mengantarkan informasi dan komunikasi dengan teknologi internet langsung diakses para pengguna handphone atau yang kemudian disebut (smartphone). Berbagai macam aplikasi dirancang untuk memenuhi kebutuhan komunikasi dan informasi, termasuk kebutuhan sosialisasi. Media sosial dengan teknologi aplikasi pun menjadi populer digunakan oleh berbagai kalangan, termasuk sebuah perusahaan dan komunitas atau organisasi.

Dalam riset ini, penulis bermaksud untuk menganalisis peran media sosial dan strategi kreatif kampanye yang dijalankan organisasi ini dalam kurun waktu tiga tahun dari 20132015. Pasalnya dalam tiga tahun ini Rumah Cemara berhasil mengundang perhatian bukan saja para pengidap HVI/AIDS dan pecandu narkoba, tetapi masyarakat umum Kota Bandung terhadap problematika diskriminasi ini. Rumah Cemara berhasil mendapat bantuan dan sponsor bahkan dari luar negeri untuk ikut serta dalam kegiatan sepakbola International Homeless Worldcup (sebuah ajang yang diikuti oleh organisasi sosial dan kemasyarakatan seluruh dunia) dan menjadi organisasi satu-satunya yang mewakili Indonesia dalam ajang tersebut.

\section{METODE PENELITIAN}

Melalui wawancara kepada salah satu pendiri organisasi, penulis mengharapkan adanya data mengenai latar belakang organisasi dan lini waktu mengenai program-program yang dilaksanakan oleh organisasi tersebut. Wawancara dengan bagian publikasi organisasi dimaksudkan untuk memperolehdata dan kejelasan mengenai strategi promosi dan 
publikasi media sosial dari organisasi ini. Selain metode wawancara, penulis mengumpulkan dokumentasi berupa artifak media sosial populer untuk mencermati konten-konten yang telah digunakan oleh organisasi tersebut dan kemudian menganalisis berdasarkan literatur mengenai strategi kreatif kampanye dan media sosial dalam ranah perancangan kampanye. Adapun teori yang digunakan dalam penulisan ini adalah sebagai berikut:

\section{Kampanye}

Menurut Rogers dan Storey (1987) yang dikutip oleh Venus (2004) dalam bukunya yang berjudul Manajemen Kampanye, kampanye dapat didefinisikan sebagai "serangkaian tindakan komunikasi yang terencana dengan tujuan menciptakan efek tertentu pada sejumlah besar khalayak yang dilakukan secara berkelanjutan pada kurun waktu tertentu". Merujuk pada definisi tersebut maka setiap aktivitas kampanye komunikasi harus mengandung empat hal, yaitu: (1) tindakan kampanye yang ditujukan untuk menciptakan efek atau dampak tertentu (2) jumlah khalayak sasaran yang besar (3) biasanya dipusatkan dalam kurun waktu tertentu (4) melalui serangkaian tindakan komunikasi yang terorganisasi (Venus, 2004).

Menurut Klingeman dan Romelle (2002) dalam Venus (2004), membedakan cara berkampanye ke dalam kampanye informatif dan kampanye komunikatif.Kampanye informatif dilakukan secara satu arah (undirectional) dengan pesan-pesan kampanye mengalir secara linear dari sumber kepada penerima, tidak terjadi dialog antara pelaku dan penerima kampanye. Pelaku kampanye hanya sepenuhnya mengandalkan media massa (media oriented) untuk menyalurkan pesan-pesannya. Hal ini berbeda dengan jenis kampanye komunikatif yang berorientasi pada khalayak dan menekankan pentingnya interaksi dan dialog dengan khalayak sasaran (Venus, 2004).

Berdasarkan aspek tujuan kampanye, dibedakan menjadi dua macam kampanye, yaitu kampanye informatif dan persuasif. Kampanye disebut informatif apabila bertujuan memberikan informasi, melakukan perubahan pada tataran kognitif, menggugah kesadaran khalayak tentang isu tertentu. Sementara kampanye persuasif ditandai oleh tujuannya yang bersifat mengajak dan menganjurkan perubahan pada tataran afektif dan behavioral (Venus, 2004).

\section{Prinsip Umum Persuasi dalam Kampanye}


Menurut Venus, (2004) persuasi secara inheren terkandung dalam kampanye, dengan demikian setiap tindakan kampanye pada prinsipnya adalah tindakan persuasi. Menurut Pace, Peterson dan Burnett (1979) yang ditulis dalam Venus (2004), persuasi didefinisikan sebagai tindakan komunikasi yang bertujuan untuk membuat komunikan mengadopsi pandangan komunikator mengenai suatu hal atau melakukan suatu tindakan tertentu.Dari pernyataan tersebut diatas maka dalam suatu perancangan kampanyepenting halnya prinsip dalam persuasi itu dipahami dengan seksama sehingga tujuan dari persuasi tersebut tercapai.

Adapun menurut Hogan (1996) yang ditulis dalam Venus (2004) prinsip-prinsip umum tersebut adalah:

1. Prinsip Timbal Balik; Jika manusia menerima sesuatu yang dipandang berharga, maka seketika ia akan menanggapi dengan memberikan sesuatu.

2. Prinsip Kontras; Seseorang cenderung akan memilih yang terbaik dari dua buah pilihan yang diperlihatkan relatif berbeda satu sama lain.

3. Prinsip Karena Teman; Seseorang akan melakukan hampir semua hal yang diminta oleh seorang teman kepadanya. Ini terjadi karena teman adalah orang yang disukai karena memiliki banyak persamaan.

4. Prinsip Harapan; Orang akan cenderung melakukan sesuatu yang menjadi harapan orang yang ia percayai dan ia hormati.

5. Prinsip Asosiasi; Manusia cenderung menyukai produk, jasa atau gagasan yang didukung oleh orang lain yang disukai atau dihormati.

6. Prinsip Konsistensi; Seseorang yang mempunyai pendirian tertulis atau lisan dalam sebuah persoalan akan mempunyai kecenderungan yang kuat untuk membela pendirian itu.

7. Prinsip Kelangkaan; Semakin langka sesuatu yang diinginkan, maka akan semakin besar nilainya.

8. Prinsip Kompromi; Kebanyakan orang akan menyetujui usul, produk, atau jasa yang akan dipandang bisa diterima oleh mayoritas orang lain atau mayoritas anggota kelompoknya.

9. Prinsip Kekuasaan; semakin berkuasa seseorang dipandang oleh orang lain, semakin besar kemungkinan permintaannya akan dipertimbangkan dan diterima.

Kesembilan prinsip persuasi tersebut dapat digunakan untuk membantu merancang dan 
melaksanakan berbagai tindakan persuasi dalam sebuah kampanye.

Kaitannya dengan khalayak sasaran kampanye, menurut Wiryanto (2004), suatu komunikasi yang bersifat persuasif adalah komunikasi yang bertujuan untuk mengubah atau memengaruhi kepercayaan, sikap, dan perilaku seseorang sehingga bertindak sesuai dengan apa yang diharapkan oleh komunikator. Pada umumnya sikap-sikap individu/ kelompok atau khalayak sasaran yang hendak dipengaruhi ini terdiri dari tiga komponen:

- Kognitif - perilaku yang individunya mencapai tingkat "tahu" pada objek yang diperkenalkan.

- Afektif - perilaku yang individunya mempunyai kecenderungan untuk suka atau tidak suka pada objek.

- Konatif - perilaku yang sudah sampai tahap hingga individu melakukan sesuatu (perbuatan) terhadap objek.

Pemahanan lain mengenai persuasi yang perlu dilihat sebagai sudut pandang lain dalam analisis kampanye adalah menurut Ritonga (2005) yang mengatakan bahwapersuasi merupakan suatu usaha mengubah sikap, kepercayaan atau tindakan khalayaktarget untuk mencapai suatu tujuan. Secara sederhana, persuasi yang efektif adalah kemampuan untuk menyampaikan suatu pesan di dalam suatu cara yang membuat khalayak target merasa mempunyai pilihan dan membuat mereka setuju.

\section{Pesan Kampanye}

Pesan (message) dalam ilmu komunikasi adalah isi atau maksud yang akan disampaikan oleh satu pihak kepada pihak lain. Menurut Fayol dan Taylor dalam Wiryanto (2004), masukan (input) dari "pabrik" informasi berupa stimulus yang ditangkap panca indera, selanjutnya diteruskan ke otak/ pusat syaraf. Di dalam otak, stimulus mengalami proses transformasi, yaitu diolah dengan pengetahuan, pengalaman, selera, dan kepercayaan seseorang. Keluaran (output) dari proses tersebut berupa informasi yang diingat (memory) dalam diri seseorang atau diteruskan kepada orang lain. Informasi yang dikomunikasikan kepada orang lain atau khalayak disebut dengan pesan (message). Dengan demikian semua pesan adalah informasi.

Definisi informasi (pesan) menurut Shannon dan Weaver dalam Wiryanto (2004) bahwa informasi adalah hasil dari proses intelektual seseorang. Proses intelektual adalah mengolah/memroses stimulus, yang masuk ke dalam diri individu melalui panca indera, 
kemudian diteruskan ke otak/pusat syaraf untuk diolah/ diproses dengan pengetahuan, pengalaman, selera, dan kepercayaan yang dimiliki seseorang. Setelah mengalami pemrosesan, stimulus itu dapat dimengerti sebagai informasi. Informasi ini bisa diingat di otak, bila dikomunikasikan kepada individu/ khalayak, maka akan berubah menjadi pesan.

Pesan disampaikan atau dibawa melalui suatu media atau saluran baik secara langsung maupun tidak langsung. Unsur pesan meliputi semua materi atau isi yang dikomunikasikan antara pihak-pihak yang terlibat dalam proses komunikasi baik yang disampaikan secara verbal maupun non verbal, baik secara langsung maupun tidak langsung melalui media massa (Wiryanto, 2004).

Menurut Harjanto (2009) untuk pendekatan pesan dalam setiap kelompok masing-masing terdapat beberapa pendekatan yang dapat dilakukan, diantaranya adalah sebagai berikut:

- Penggalan Kehidupan (Slice of Life); menggunakan peristiwa sehari-hari yang dihubungkan oleh suatu produk.

- Animasi; menggunakan teknik komputer animasi sebagai daya tarik visual.

- Khayal (Fantasy); lebih menggunakan efek-efek khusus untuk menciptakan tempat, peristiwa, atau karakter bayangan.

- Bukti Ilmiah (Scientific Evidence); menampilkan hasil survei atau bukti ilmiah.

- Demonstrasi (Demonstration); menggambarkan keuntungan dan manfaat dengan menunjukkan penggunaan aktualnya.

- Berita (News); berbentuk berita atau pengumuman tentang produk atau perusahaaan terkait.

- Masalah \& Solusi; misalnya mendramatisasi masalah dan memberikan solusi bagaimana produk dapat memecahkannya.

- Popularitas; menggunakan ketenaran suatu produk yang terbangun karena mutu, nilai, ataupun manfaat kompetitifnya dibanding pesaing.

- Gaya Hidup; menunjukkan kesesuaian sebuah produk dengan gaya hidup tertentu dari khalayak sasarannya.

- Suasana Hati; rancangan iklan hanya berupaya untuk merefleksikan suasana hati pengguna, ataupun citra tentang produk terkait

- Citra; merupakan pengkondisian untuk menciptakan citra produk atau perusahaan.

- Musikal; menggunakan musik yang dijadikan pengantar pesan kunci dan mengisi adegan. 
- Endorsement; artis atau selebriti yang menyampaikan janji atau klaim produk.

- Kesaksian (Testimonial); Memanfaatkan penyaji atau juru bicara yang mengunggulkan suatu produk.

- Simbol Kepribadian; menggunakan pribadi atau karakter tertentu untuk mewakili produk.

- Keahlian Teknis; menonjolkan keahlian atau pengalaman sebuah perusahaannya.

- Penyajian Produk (Product Presentation); produk ditampilkan sebagai tokoh utama atau fokus utama.

\section{Strategi Kreatif Persuasi dalam Kampanye}

Strategi memegang peranan vital dalam penentuan keberhasilan kampanye.Strategi merupakan dasar membangun merek, strategi menjaga agar kampanye berada dalam jalur yang tepat serta membangun citra dengan jelas dan konsisten.Strategi mewakili jiwa sebuah merek dan menjadi elemen penting untuk keberhasilan (Roman, Maas \& Nisenholtz, 2005).

Perloff (1993) menuliskan bahwa beberapa strategi yang dapat digunakan dalam praktik kampanye yaitu:

1. Menggunakan komunikator yang terpercaya; Untuk mengubah sebuah perilaku maka khalayak harus percaya kepada komunikator, karena alasan ini maka kredibilitas komunikator harus baik dan dapat dipercaya juga disesuaikan dengan khalayak.

2. Pesan sesuai dengan keyakinan khalayak; Bahwa pesan dan tema utama kampanye harus dikemas dan disesuaikan dengan kepercayaan khalayak.

3. Memunculkan kekuatan diri khalayak; Khalayak harus disadarkan bahwa mereka mempunyai kemampuan untuk dapat mengubah perilaku yang diharapkan.

4. Mengajak Khalayak Untuk berpikir; dapat memunculkan pemikiran positif dalam diri khalayak termasuk menyajikan data statistik atau temuan penelitian yang relevan.

5. Menggunakan Strategi Pelibatan; Pesan kampanye harus disampaikan sesuai dengan strategi pelibatan. Tingkat keterlibatan sangat bergantung pada jenis khalayak .

6. Menggunakan Strategi Pembangunan Inkonsistensi; Memunculkan pesan yang menimbulkan disonansi karena tidak cocok dengan apa yang khalayak yakini, ketidakcocokan tersebut diharapkan dapat membuat khalayak bertindak sesuatu. 
7. Membangun Resistensi Terhadap Pesan Negatif; Menggunakan pesan negatif yang berlawanan terhadap isu yang kemudian menambahkan dengan kontra-argumen yang mematikan pesan negatif tersebut.

\section{Media Sosial}

Teknologi media dalam komunikasi terus berkembang dengan pesat. Perkembangan teknologi dalam komunikasi ini sendiri juga membawa pengaruh pada proses kampanye. Media online jejaring sosial sebagai salah satu teknologi komunikasi yangtelah banyak dipergunakan dalam kampanye.

Dengan begitu banyaknya jenis dan pengguna, sosial media mempunyai dampak dan dengan secara sengaja memanfaatkan sosial media untuk dapat mencapai tujuan yang hendak dicapai hampir dalam segala aspek kehidupan (Grant, 2010).

Definisi dari sosial media adalah sebagai berikut:

“... social network sites as web-based services that allow individuals to (1) construct a public or semi-public profile within a bounded system, (2) articulate a list of other users with whom they share a connection, (3) view and traverse their list of connections and those made by others within the system. The nature and nomenclature of these connections may vary from site to site ..." (Boyd, 2007).

Dari definisi tersebut diatas dapat diartikan bahwa media sosial membangun profil dalam sebuah sistem yang kemudian dapat memilih dengan siapa profil tersebut terkoneksi dan daftar koneksi tersebut dapat terlihat dan saling terhubung.

Menurut Zarella (2010), jejaring sosial (social network) adalah situs yang menjadi tempat orang-orang berkomunikasi dengan teman, yang mereka kenal di dunia nyata dan dunia maya. Situs-situs jejaring sosial mempunyai fitur yang sangat bervariasi, tapi kebanyakan memiliki elemen yang sama. Elemen-elemen tersebut adalah:

Profil; memuat informasi hingga riwayat tentang pengguna. Koneksi; Peran terpenting dalam jejaring sosial yang dapat menghubungkan dua orang atau lebih. Pesan Pribadi; layanan pengiriman pesan secara pribadi diantara pengguna situs. Pesan Terbuka; biasa disebut kolom komentar yang dapat dibaca oleh pengguna situs. Grup; konsep fitur grup adalah untuk mempersatukan pengguna dengan minat yang sama. Foto; berbagi foto, merupakan fitur paling populer. Kegiatan; fasilitas untuk mengumumkan kegiatan yang dilakukan dan dapat juga mengundang teman untuk mengikutinya. Aplikasi; Fasilitas atau 
fitur API (Application Programming Interface) yang terhubung dengan situs tersebut atau berfungsi sebagai add-on (fasilitas tambahanpada profil). Status Update; Serupa dengan instant messaging dengan bentuk pesan terbuka dan dapat dikomentari oleh pengguna lain.

Menurut Arens dan Weigold (2011) dalam Contemporary Advertising \& Integrated Marketing Communication, tipe media sosial dibagi menjadi 8 tipe, yaitu: Forums, Weblogs, Microblogs, Wikis, RSS (Really Simple Syndication), Social Bookmarking, Social Networking, The Data Explotion. Kaitannya dengan sosial media yang digunakan dalam objek penelitian ini yaitu Facebook yang merupakan tipe Social Networkingyaitu media memiliki pelayanan untuk terkoneksi dengan orang lain yang memiliki latar belakang dan ketertarikan yang sama. Media kedua adalah Twitter yang merupakan tipe Microblogyaitu media yang mampunyai layanan yang berfokus pada update pendek atau singkat kepada siapapun yang menjadi pengikut sebuah akun profil tertentu. Kemudian Youtube dengan tipe Weblogs Media Sharingyaitu media yang memiliki layanan untuk mengunggah bentuk informasi lain yaitu gambar bergerak atau video.Penjelasan mengenai ketiga media diatas akandijelaskan berikut ini:

\section{Media Facebook}

Menurut Zarella (2013), segmen pengguna Facebook tercatat berumur antara 35 - 54 tahun belakangan ini. Bukan hanya para pengguna pribadi tetapi banyak perusahaan dan organisasi yang mempunyai halaman Facebook untuk kepentingan/ kegiatan bisnis maupun kampanye. Media Facebook memiliki elemen-elemen fitur seperti yang telah disebutkan diatas ditambah dengan fitur privacy setting yang memberikan pengguna fitur untuk menentukan kelompok mana saja yang dapat terhubung dengan pengguna.

Facebook didirikan pada tahun 2004, kini pengguna situs ini mencapai 600 juta orang.Pada April 2010, menurut Harian The New York Times, pengguna terbanyak berasal dari negara Amerika Serikat, Inggris, dan Indonesia. Indonesia telah menjadi negara dengan jumlah pengguna terbanyak kedua setelah Amerika Serikat dengan populasi sekitar 24 juta pengguna atau 10 persen dari total penduduk Indonesia.

\section{Media Twitter}

Microblogging adalah bentuk blogging yang membatasi ukuran setiap post-nya. Contohnya adalah Twitter yang hanya berisi 140 karakter. Pembatasan ini melahirkan fitur-fitur, protokol-protokol dan perilaku yang sangat unik di media tersebut. Twitter mulai populer 
pada awal 2009 (Zarella, 2013). Kebanyakan perusahaan hadir di Twitter, penggunaannya sangat mudah hanya memerlukan sedikit waktu dan dapat membuat berita menjadi buah bibir dengan cepat. Twitter dapat dimanfaatkan untuk meningkatkan penjualan, menyampaikan tawaran, memberikan peristiwa, dan menghubungkan pengguna dengan berita-berita penting beserta tautannya. Fitur yang populer dari Twitter adalah fungsi retweet yakni follower (pengikut suatu profil) dapat mengunggah ulang posting pengguna. Jumlah pengikut (follower) dari seorang pengguna adalah jumlah orang yang berpotensi membaca tweet pengguna tersebut.Maka untuk memperluas jangkauan, seorang pengguna harus mencari lebih banyak pengikut.

Twitter mengembangkan algoritma yang dapat melacak penggunaan kata-kata dan frasa yang paling sering digunakan, istilahnya sering disebut sebagai Trending Topic. Untuk menyambungkan pendapat atau percakapan ke halaman Twitter penggunalain dengan lebih fleksibel, pengguna dapat menggunakan Hashtag (simbol \#). Twitter lebih banyak digunakan untuk pemberitaan dan promosi dibanding dengan konten pribadi (Zarella, 2013).

\section{Media Youtube}

Youtube didirikan pada tahun 2005.Youtube merupakan situs video bersama terbesar di web dan merupakan situs ketiga yang paling sering dikunjungi.Pemasaran yang dilakukan melalui Youtube dipastikan mendapat keuntungan.Akun pengguna Youtube disebut dengan Channel (Kanal).Youtube adalah tempat untuk mengunggah format video di sebuah halaman lepas pada web.Seseorang dapat menjadi pengikut akun tertentu.Dengan menggunakan format video sebagai konten pesan, sangat memungkinkan para pengiklan untuk menyisipkan promosi. Media Youtube sangat efektif untuk memuat konten-konten yang lebih padat, persuasif, tetapi video lebih efektif jika dalam durasi yang singkat, karena untuk memuat video biasanya diperlukan koneksi yang cukup cepat sehingga audien atau pengguna dapat langsung memutar video secara lengkap. Dalam Youtube terdapat fitur angka yang dapat dilihat jika video tersebut sudah dilihat oleh berapa banyak pengguna (Zarella, 20183).

\section{PEMBAHASAN}

Dalam bagian pembahasan ini, penulis akan menganalisis objek yaitu kampanye media sosial Rumah Cemara berdasarkan teori-teori yang sudah dituliskan diatas. Analisis berdasarkan teori dan hasil data wawancara dari pihak Rumah Cemara akan dipaparkan sesuai urutan sebagai berikut: 


\section{Kampanye Sosial Rumah Cemara}

Media sosial adalah salah satu media yang digunakan Rumah Cemara dalam menjalankan program kampanyenya.Media sosial yang digunakan yaitu Facebook, Twitter, dan Youtube.Hal ini ditujukan agar program atau materi kampanye tersampaikan secara lebih luas dan menjangkau khalayak sasarannya. Khalayak sasaran yang dijangkau terbagi menjadi tiga macam:anggota rehabilitasi Rumah Cemara, masyarakat yang hidup dengan HIV/AIDS dan masyarakat umum lainnya dengan target usia remaja hingga dewasa di Jawa Barat. Facebook digunakan semenjak tahun 2003 yang hingga kini sudah mempunyai koneksi teman sebanyak 4999 orang. Media Twitter digunakan semenjak 2010, mempunyai pengikut (follower) sebanyak 20.000 akun dan telah mengunggah 30.500 tweet.Media Youtube digunakan sejak 2013 dengan 103 orang subscribers (pelanggan kanal video), 34.864 views (kunjungan pada akun).

Dari penggunaan media dalam kampanyenya dapat dilihat bahwa Rumah Cemara termasuk pada jenis kampanye komunikatif.Hal ini terlihat dari sifat media yang digunakan, memungkinkan khalayak sasaran untuk ikut terlibat dan berinteraksi. Media Facebook dan Twitter merupakan media yang menyediakan kolom komentar dan tautan secara online, sehingga ketika komunikator (dalam hal ini Rumah Cemara) mengunggah isi masalah kampanye atau pemberitaan, maka siapapun profil yang terhubung maupun Follower dapat mengomentari, menautkan ulang atau menambahkan pesan sehingga hal ini menunjukkan komunikasi dua arah.

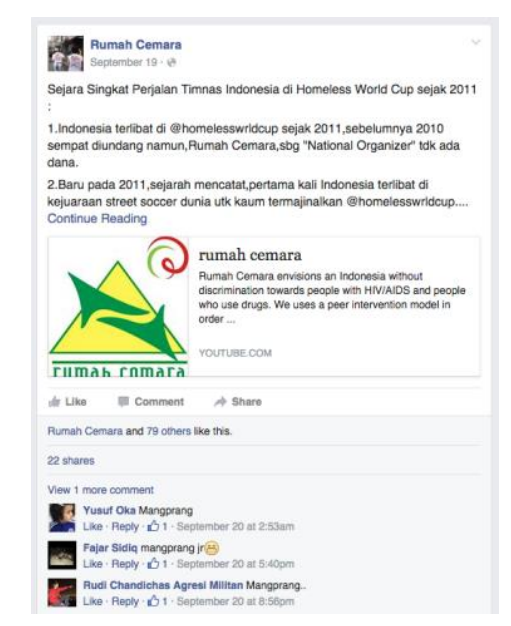

Gambar 4. Halamantimeline Facebook Rumah Cemara Sumber: www.facebook.com

Dari gambar 4 diatas dapat dilihat bahwa akun pengguna dan akun teman memberikan 
tanda like, mengisi kolom komentar dan ikut menyebarkan tautan atau isi.Dapat dilihat isi (konten) merupakan tautan dari Youtube.Hal ini menandakan bahwa khalayak dapat ikut serta secara langsung menjadi bagian dari penyebaran konten kampanye.

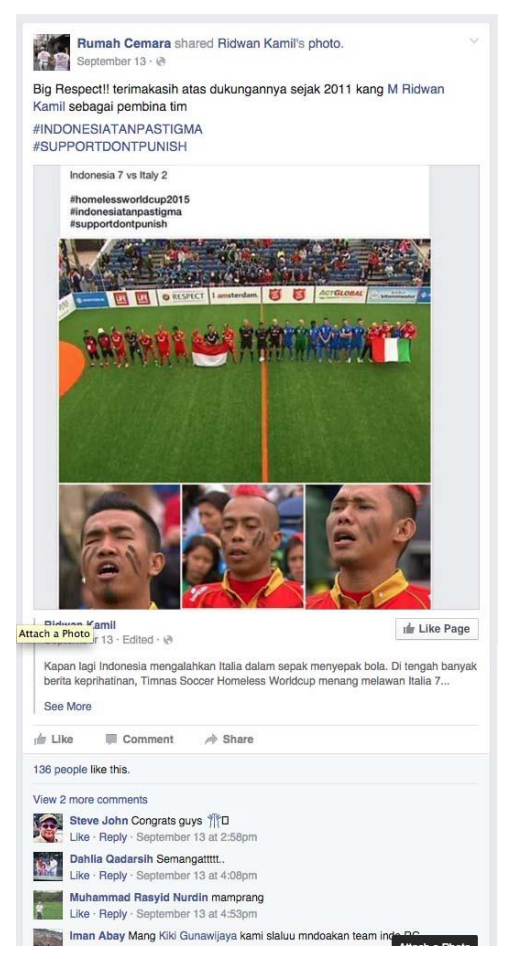

ambar 5. Halaman timeline Facebook Rumah Cemara, kampanye komunikatif Sumber: www.facebook.com

Dari gambar 5 diatas dapat dilihat bahwa akun media sosial facebook Rumah Cemara turut menyebar ulang tautan dari halaman akun lain yaitu akun Walikota Bandung Bapak Ridwan Kamil. Hal ini menandakan kampanye komunikatif dilakukan secara dua arah antara akun Rumah Cemara dan khalayak.

Kampanye Rumah Cemara dalam media sosial ini juga menggunakan jenis kampanye informatif, karena dalam beberapa unggahan konten kampanyenya terdapat materi-materi yang bersifat informatif baik bagi orang yang hidup dengan HIV/AIDS atau pengguna narkoba. 


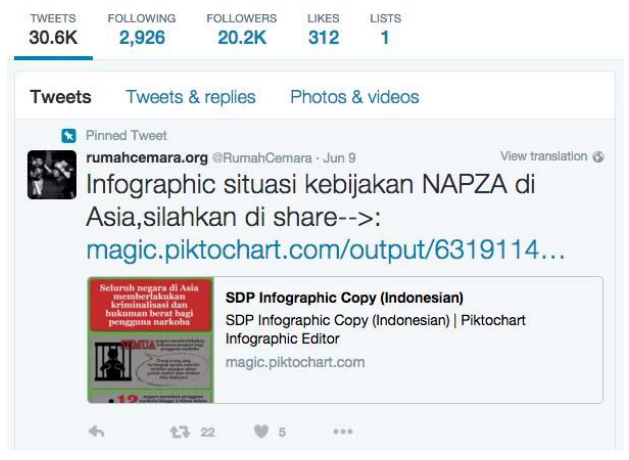

Gambar 6. Halaman timeline Twitter Rumah Cemara, kampanye informatif Sumber: www.twitter.com

Dari gambar halaman timeline Twitter Rumah Cemara diatas dapat dilihat konten materi yang disebarkan berupa informasi untuk parafollower umum maupun follower pengguna Narkoba. Pada gambar 6 berupa kebijakan yang berhubungan dengan NAPZA dan pada gambar 7adalah informasi mengenai regulasi ganja.

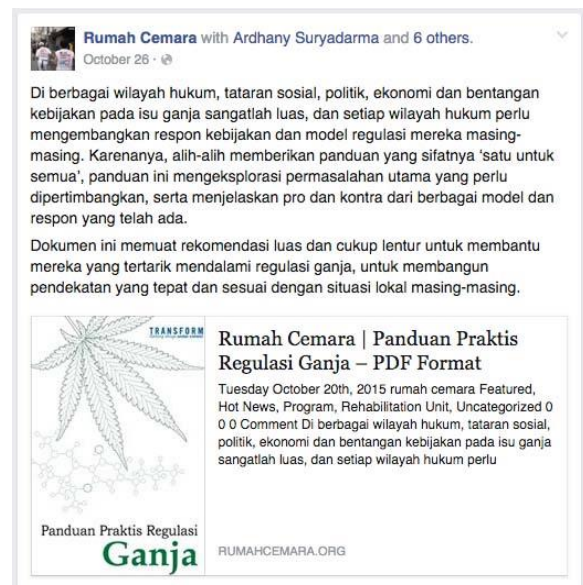

Gambar 7. Halaman timeline Facebook Rumah Cemara, kampanye informatif Sumber: www.facebook.com

Kampanye jenis persuasif cenderung tidak dilakukan oleh Rumah Cemara, hal ini dapat dilihat dari postingan atau tautan gambar-gambar yang berkaitan dengan ajakan-ajakan maupun anjuran untuk mengarahkan kepada perubahan perilaku kepada khalayak target sangat sedikit dalam lini waktu halaman media sosialnya. Pada gambar 8, gambar ditautkan oleh gerakan sosial "ODHA Berhak Sehat" berkenaan dengan anjuran penggunaan obat ARV untuk menekan penggandaan virus bagi orang yang hidup dengan HIV/AIDS.Tautan ini kemudian di-retweet oleh Rumah Cemara agar dapat di-share kepada follower-nya.Hal ini berarti Rumah Cemara tidak melakukan tindakan persuasif secara langsung. 


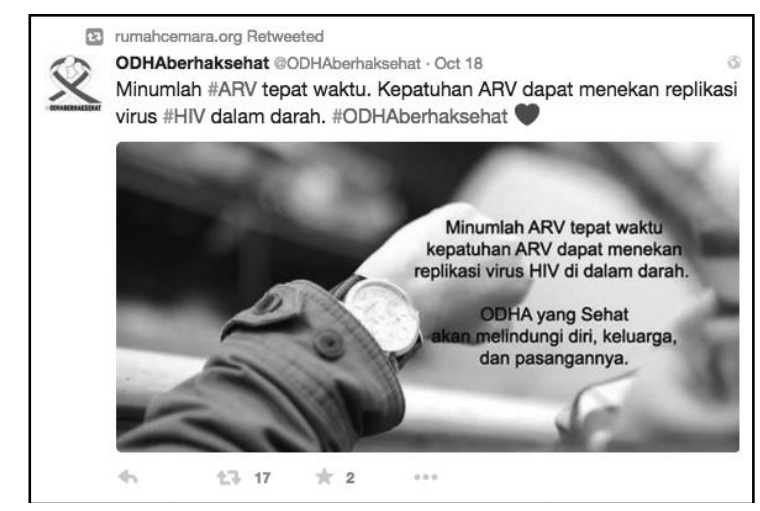

Gambar 8. Halaman timeline Twitter Rumah Cemara, tautan dari akun ODHA berhak sehat, Kampanye Persuasif Sumber: www.twitter.com

\section{Prinsip Persuasi Kampanye Sosial \\ Rumah Cemara}

Tindakan komunikasi yang digunakan Rumah Cemara dalam konten kampanye di media sosial lebih menggunakan prinsip persuasi asosiasi. Prinsip asosiasi yang dimaksud adalah cenderung mengenai gagasan yang didukung oleh orang lain yang disukai atau dihormati. Seseorang yang menyukai orang lain yang berhubungan dengan suatu gagasan, cenderung akan mempunyai asosiasi positif tentang gagasan yang mereka dukung.

Hal ini terlihat dari komunikator atau Rumah Cemarayang lebih sering mengunggah gambar atau pemberitaan dari prestasi olahraga yang dilaksanakan oleh Rumah Cemara.Dari gambar dan tulisan terkesan agar khalayak ikut mendukung program kampanye melalui prestasi olahraga dan diberi contoh oleh para ODHA atau pengguna narkoba yang berprestasi (gambar 9).

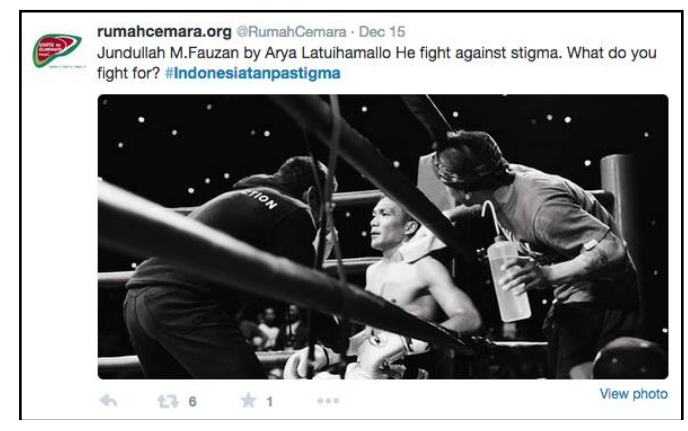

Gambar 9. Halaman Timeline Twitter Rumah Cemara Sumber: www.twitter.com

Kaitannya dengan khalayak sasaran kampanyepada umumnya sikap-sikap individu atau khalayak sasaran yang hendak dipengaruhi ini sesuai dengan komponen sikap afektifyaitu perilaku khalayak yang cenderung suka atau tidak suka dengan objek. Sikap ini dapat dilihat 
dari setiap komentar atau tombol like yang terdapat dibawah tautan konten kampanye seperti contoh pada gambar 10 .

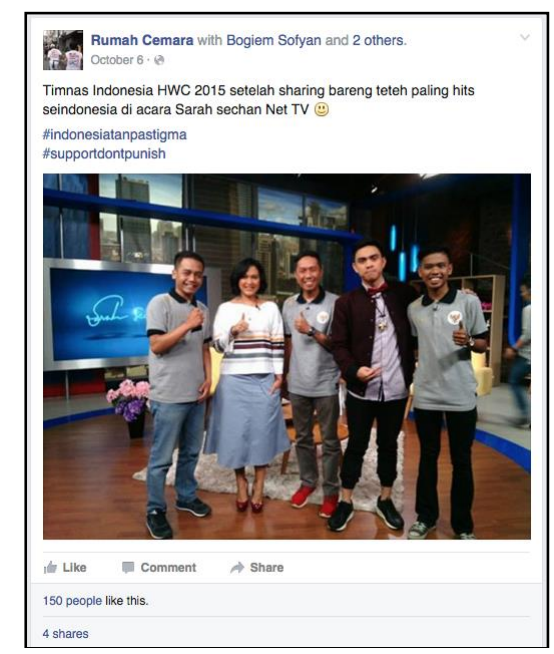

Gambar 10. Halaman Timeline Facebook Rumah Cemara dengan ikon like lebih dari 100 orang Sumber: www.facebook.com

Dari berbagai macam jenis konten yang ditautkan pada halaman akun Rumah Cemara terlihat bahwa tombol ikon likedan komentar mendukung banyak diberikan untuk pemberitaan atau konten kampanye yang berkaitan dengan prestasi atau pencapaian komunikator, contoh seperti di bawah ini

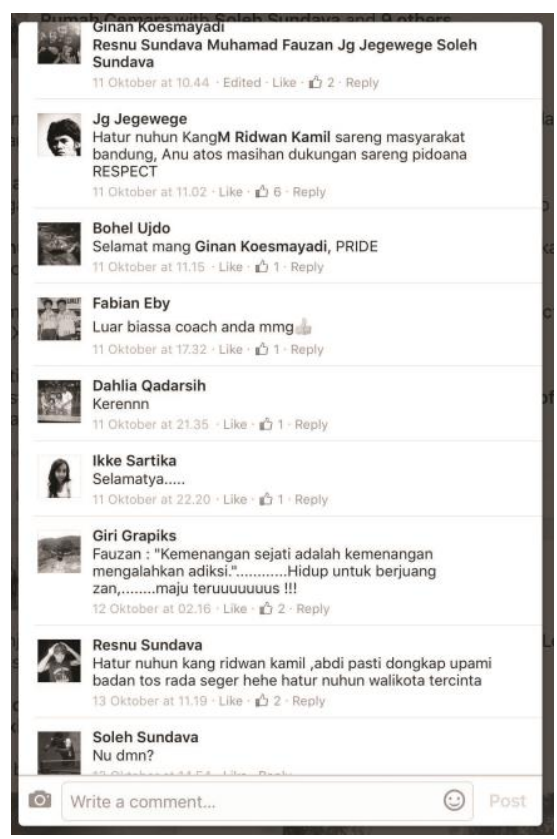

Gambar 11. Halaman Timeline Facebook Rumah Cemara, komentar pada prestasi olahraga Sumber: www.facebook.com

Dari konten kampanye beserta hasil mencermati tanggapan dari khalayak dapat dikatakan bahwa pendekatan persuasi yang dijalankan termasuk pada kategori campuran, yaitu kategori rasional dan emosional.Kategori rasional dinilai dari banyaknya konten 
pemberitaan dan keadaan sesungguhnya ataupun konten yang lebih memberikan informasi, dalam hal ini komponen kognitif pada diri seseorang dapat dipengaruhi.Sedangkan kategori emosional terlihat lebih sedikit pada media sosial Facebook dan Twitter, tetapi pada unggahan di media Youtube, konten lebih menyentuh aspek afeksi yaitu hal yang berkaitan dengan kehidupan emosional seseorang. Melalui cara emosional, aspek simpati dan empati seseorang dapat digugah. Konten emosional ini berupa video tentang profil dan sejarah lembaga tersebut, salah satu pendiri Rumah Cemara (Ginan Koesmayadi) dan sekilas program kampanye melalui olahraga.

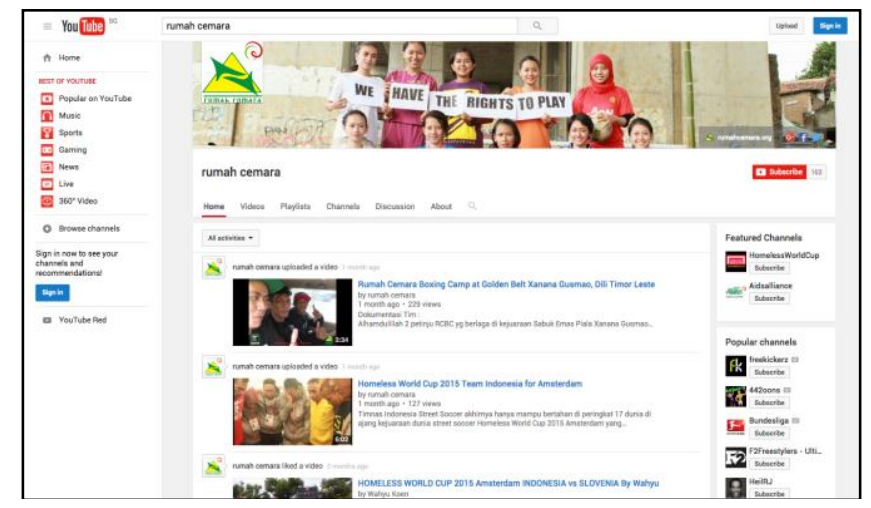

Gambar 12. Halaman Timeline Youtube Rumah Cemara Sumber: www.youtube.com

Dari konten video yang ada di media Youtube dapat dilihat bahwa sebagian besar tautan video adalah dokumentasi dari kegiatan (gambar 12).Diantara tautan tersebut terdapat video profil yang lebih menyentuh aspek afeksi karena isi video tersebut lebih mengundang simpati (gambar 13). 


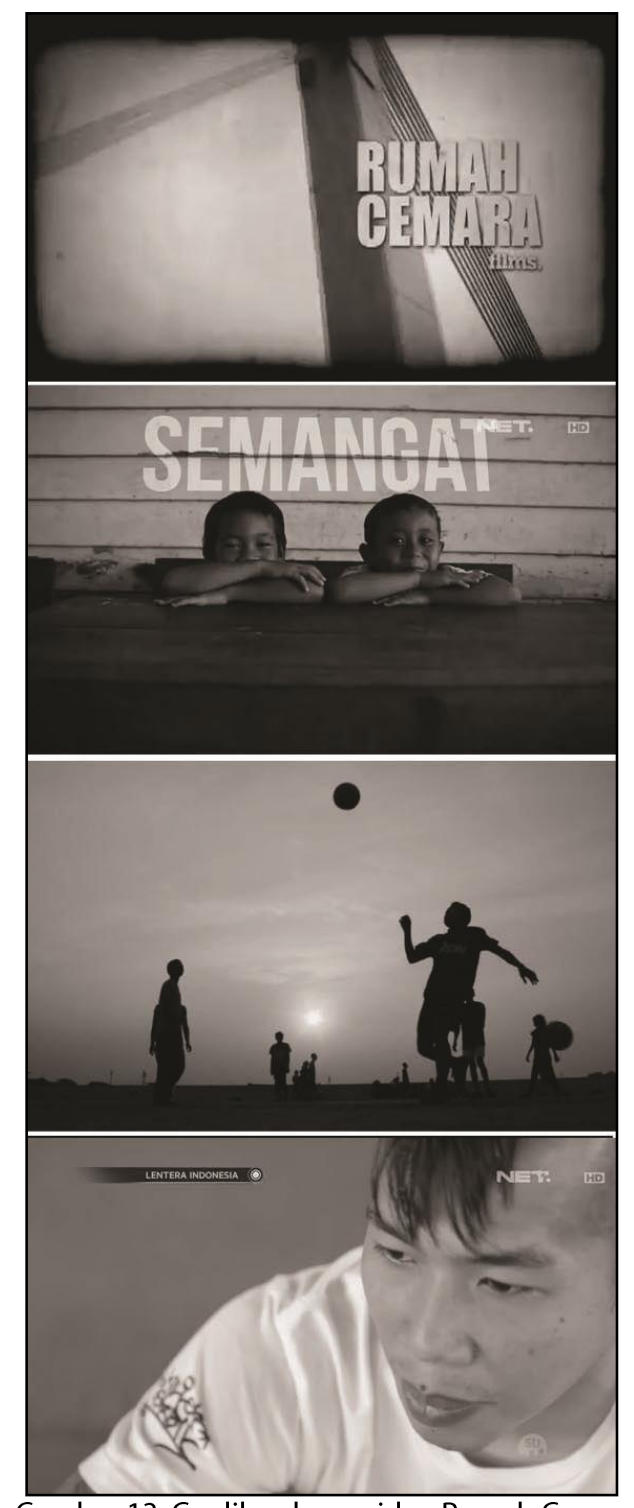

Gambar 13. Cuplikan layar video Rumah Cemara

di media sosial Youtube

Sumber: www.youtube/rumahcemara

Setelah diamati dari konten media sosialnya, baik di Facebook, Twitter dan Youtube, model persuasi yang digunakan (berdasarkan teori Lerbinger,1972) kampanye lebih menggunakan model motivasi yang lebih cenderung mendorong khalayak kepada perilaku-perilaku positif dan model kognitif yang lebih menekankan penjelasan rasional dan logis mengenai permasalahan dalam kampanye.

Jika dikaitkan dengan teori Weinrich (1999), kampanye lebih cenderung menggunakan model keyakinan kesehatan yaitu lebih menjelaskan kondisi yang diperlukan untuk suatu perubahan perilaku yang menyinggung tentang persepsi akan kelemahan individu yang hidup dengan HIV/AIDS dan Narkoba, juga jika dianalisis dari setiap kata motivasi, jargon 
"mamprang" tampilan foto maupun video yang terkesan "menyemangati" lebih kepada model isyarat untuk bertindak (clues to action). Dari semua konten pesannya lebih kepada model persuasi teori pembelajaran kognitif social yakni perubahan perilaku dipengaruhi oleh individu itu sendiri dan lingkungannya.

Pendekatan pesan kampanye dibuat dalam beberapa variasi seperti pendekatan penggalan kehidupan (Slice of Life) dan simbol kepribadian.Hal ini bisa dicermati dari konten mengenai Ginan Koesmayadi (salah satu pendiri Rumah Cemara, pengidap HIV dan mantan pengguna narkoba) yang menjadi ikon dan simbol dari Rumah Cemara itu sendiri (gambar 14 dan 15).Pendekatan endorsement juga pernah dilakukan dengan menggunakan grup musik asal Bandung yaitu The Changcuters (gambar 16).

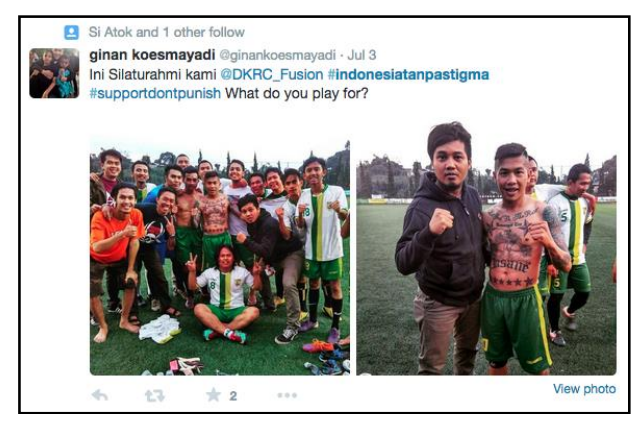

Gambar 14. Tautan konten mengenai Sosok Inspiratif Rumah Cemara Sumber: www.twitter.com

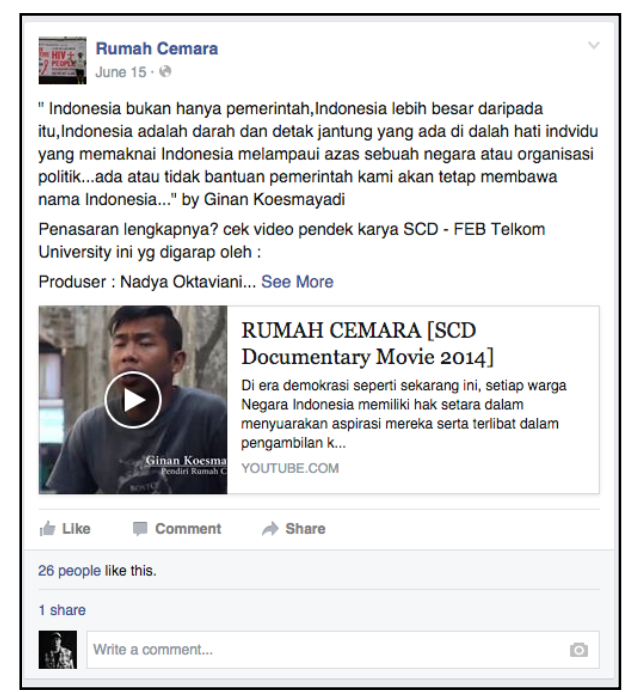

Gambar 15. Tautan konten mengenai Sosok Inspiratif Rumah Cemara Sumber: www.facebook.com 


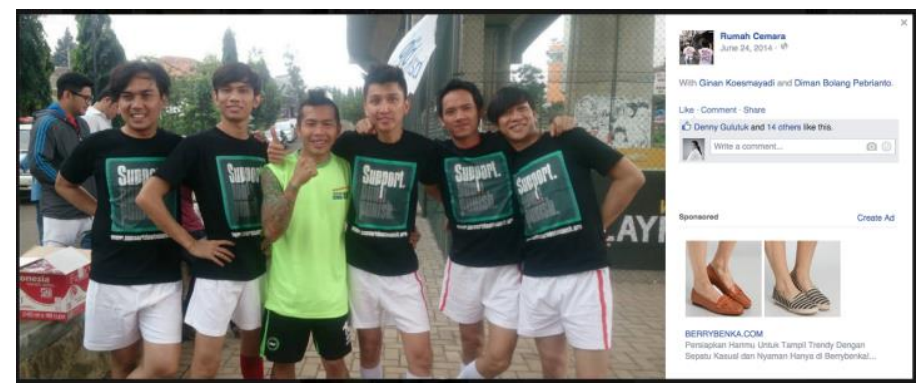

Gambar 16. Endorsement Grup Musik The Changcuters Sumber: www.facebook.com

\section{Strategi Kreatif Kampanye Sosial Rumah Cemara melalui Media Sosial}

Jika dianalisis menggunakan teori Perloff (1993) mengenai beberapa strategi yang dapat digunakan dalam praktik kampanye dan dikaitkan dengan prinsip persuasi dan pendekatan pesan kampanye, maka dapat dirumuskan bahwa strategi kampanye yang dilakukan oleh Rumah Cemara dapat dijelaskan sebagai berikut :

1. Menggunakan komunikator yang terpercaya; Menggunakan sosok inspiratif (Ginan Keosmayadi) untuk mengubah sebuah perilaku yang dipercaya khalayak sehingga kredibillitas komunikator menjadi positif.

2. Memunculkan kekuatan diri khalayak; Banyak konten yang memotivasi dan memberi contoh sehingga khalayak disadarkan bahwa mereka mempunyai kemampuan untuk dapat mengubah perilaku yang diharapkan.

3. Mengajak khalayak untuk berpikir; menyajikan data statistik yang dapat memunculkan pemikiran positif dalam diri khalayak .

4. Menggunakan strategi pelibatan; membuat khalayak ikut dan terlibat membagi tautan sehingga persebaran kampanye lebih luas.

\section{PENUTUP}

Dari hasil analisis yang dilakukan didapat kesimpulan bahwa: Kampanye yang dilakukan oleh komunikator (Rumah Cemara) menggunakan media sosial populer yaitu Facebook, Twitter, dan Youtube secara aktif.

Konten dari semua media sosial yang digunakan lebih bersifat pemberitaan dan bukan ajakan langsung yang menggunakan gambar-gambar persuasif.Sehingga pendekatan rasional lebih condong dilakukan oleh komunikator. 
Kedudukan media sosial dalam program kampanye komunikator lebih kepada persebaran tautan dokumentasi dan motivasi dalam bentuk kata dan foto sehingga dengan sifat medianya, persebaran kampanye sangat melibatkan khalayak. Strategi yang dilakukan dalam kampanye komunikator pada akhirnya membentuk citra komunikator sendiri.Hal ini dibantu dengan jargon-jargon yang lebih provokatif yang ditautkan dalam bentuk hashtag dan mengangkat sosok inspiratif dari komunikator.

Ketiga media sosial yang digunakan telah berjalan selaras (konten yang sama dalam masa program yang sedang berjalan), sehingga keunikan dan sifat dari ketiga media yang berbeda-beda ini dapat dimaksimalkan sesuai dengan rata-rata pengguna media tersebut. Kampanye Rumah Cemara yang dilakukan lebih melalui kegiatan olahraga, maka tautan tentang kegiatan dan prestasi menjadi sangat penting. Hal ini sudah dilakukan oleh komunikator dengan selalu mengunggah konten mengenai kegiatan dan prestasi, sehingga diharapkan menjadi konten yang memotivasi dan mengajak khalayak untuk mengubah pola perilaku atau pemikiran, baik tentang orang yang hidup dangan HIV/ AIDS maupun pengguna Narkoba.

Ketiga media sosial ini lebih banyak digunakan untuk mendukung konten dari website resmi Rumah Cemara sehingga media website dapat dikatakan sebagaimedia utama dan media sosial sebagai media pendukung. Berkaitan dengan perihal website, hasil observasi menunjukkan bahwa media utama komunikatorkurang terpelihara dengan baik (terlihat dari sedikitnya konten yang terbaharui), sehingga dapat disimpulkan bahwa media sosial menjadi bagian penting dari kampanye sebagai media yang paling cepat terbaharui dan dapat diakses oleh khalayak.

Dalam kampanye melalui media sosial, konten berupa tulisan atau copywriting menjadi lebih penting dibanding konten visual seperti desain poster, gambar, foto publikasi dan lain sebagainya. Hal ini terlihat dari analisis pada media sosial Twitter dan sebagian kecil pada media Facebook.

Kesimpulan umum yang penulis rumuskan dari hasil analisisyaitu untuk perancangan sebuah kampanye sosial dapat dikatakan bahwa media sosial mempunyai peranan yang sangat penting, tidak hanya untuk menyampaikan konten kampanye saja, tetapi untuk menggiring khalayak kepada media utama atau malah bertindak sebagai agen-agen publikasi yang aktif. 
Media sosial harus dirancang sebagai bagian dari alat kampanye yang efektif, harus diposisikan sesuai dengan tujuan kampanye dan konten media sosial dalam kampanye merupakan bagian dari strategi kreatif kampanye.

\section{DAFTAR PUSTAKA}

Arens, William F., Weigold, Michael F., Arens Christian. (2011). Contemporary Advertising \& Integrated Marketing Communications. New York, USA: Mcgraw - Hill//rwin.

Boyd, d. m. (2007).Social network sites:Definition, history, and scholarship. Journal of Computer-Mediated Communication, 13(1), article 11.

Castells, Manuel. (2000) The Rise of The Network Society.Victoria, Australia: BlackwellPublishing.

Grant, A. E. (2010).Communication Technology Update and Fundamental. Boston: Focal Press Johnson, T. J. (2007).Every blog has its day: Politically-interested Internet users' perceptions of blog credibility. Journal of Computer-Mediated Communication, 13(1), article 6.

Harjanto, R. (2009). Prinsip - Prinsip Periklanan. Jakarta, Indonesia: PT. Gramedia Pustaka Utama.

Lerbinger, O. (1972) .Design for Persuasive Communication. New Jersey, USA: Prentice Hall. Perloff, Richard M. (1993). The Dynamic of Persuasion.Hillsdale, NJ:Lawrence Erlbaum Associates.

Ritonga, J. (2005). Tipologi Pesan Persuasif. Jakarta, Indonesia: PT. Indeks.

Roman, Maas \& Nisenholtz. (2005). How to Advertise: Membangun Merek dan Bisnis dalam Dunia Pemasaran Baru. Jakarta: PT. Elex Media Komputindo.

Straubhaar, J. L. (2012). Media Now: Understanding Media, Culture and Technology. 7th edition, Belmont: CA:Wadsworth. Watts, S. A. (2007).Evaluative feedback: Perspectives on media effects. Journal of Computer-Mediated Communication," 12(2), article 3.

Tamburaka, Apriadi ( 2013). Literasi Media: Cerdas Bermedia Khalayak Media Massa. Rajagrafindo Persada. Jakarta, Indonesia.

Venus, Antar(2004). Manajemen Kampanye: Panduan teoritis dan Praktis dalam Mengefektifkan Kampanye Komunikasi. Simbiosa Rekatama Media. Bandung, Indonesia.

Wiryanto (2004).Pengantar Ilmu Komunikasi. Jakarta, Indonesia: PT. Grasindo. Zarella, Dan (2010). The Social Media Marketing Book. O'Reilly Media Inc. Sebastopol, CA. USA 